\title{
Enhanced muscle strength with carbohydrate supplement two hours before open cholecystectomy: a randomized, double-blind study
}

\section{Melhora da força muscular com suplemento contendo carboidratos duas horas antes de colecistectomia por laparotomia: estudo randomizado e duplo cego}

Marcella Giovana Gava'; Heloísa Michelon Castro-Barcellos'; Cervantes Caporossi, tCBC-MT1; José Eduardo de AguilarNASCIMENTO, TCBC-MT'

\section{A}

\begin{abstract}
Objective: to investigate the effects of preoperative fasting abbreviation with oral supplementation with carbohydrate in the evolution of grip strength in patients undergoing cholecystectomy by laparotomy. Methods: we conducted a clinical, randomizeddouble blind study with adult female patients, aged 18-60 years. Patients were divided into two groups: Control Group, with fasting prescription 6-8h until the time of operation; and Intervention Group, which received prescription of fasting for solids 68 hefore surgery, but ingested an oral supplement containing $12.5 \%$ carbohydrate, six (400ml) and two (200ml) hours before theprocedure. The handgrip strength was measured in both hands in both groups, at patient's admission (6h before surgery), the immediate pre-operative time (1h before surgery) and 12-18h postoperatively. Results: we analyzed 27 patients, 14 in the intervention group and 13 in the control group. There was no mortality. The handgrip strength (mean [standard deviation]) was significantly higher in the intervention group in the three periods studied, in at least one hand: preoperatively in the dominant hand (27.8 [2.6] vs 24.1 [3.7] kg; $\mathrm{p}=0.04)$, in the immediate preoperative in both hands, and postoperatively in the non-dominant hand (28.5 [3.0] vs 21.3 [5.9] kg; $p=0.01$ ). Conclusion: the abbreviation of preoperative fasting to two hours with drink containing carbohydrate improves muscle function in the perioperative period.
\end{abstract}

Key words: Fasting. Carbohydrates. Muscle Strength. Cholecystectomy. Preoperative Care.

\section{INTRODUCTION}

M odern Anesthesiology guidelines support the reduction of preoperative fasting ${ }^{1-3}$. These guidelines recommend a shift from overnight fasting of six to eight hours to an approach in which solid foods are allowed up to 6-8 hours and clear fluids with carbohydrates $(\mathrm{CHO})$ up to two hours before anesthesia induction ${ }^{4-7}$. Several studies show that intake of clear liquids with $\mathrm{CHO}$ up to two to three hours before the operation is safe and is not related to anesthetic complications or mortality risk ${ }^{8}$.

Prolonged preoperative fasting increases insulin resistance and induces gluconeogenesis ${ }^{9,10}$. Together with the metabolic response to trauma, prolonged fasting can in theory increase muscle proteolysis and impair muscle function in the early postoperative period ${ }^{11-13}$. Functional tests such as grip strength (dynamometry - DM) can detect these early changes in muscle function and thus demonstrate loss of functional capacity associated with prolonged fasting ${ }^{14-16}$. The objective of this study was to investigate the effects of preoperative fasting abbreviation with oral supplementation containing $\mathrm{CHO}$ in Handgrip Strength (HGS) in patients undergoing cholecystectomy by laparotomy.

\section{METHODS}

This is a prospective, randomized, double-blind clinical study, with therapeutic intervention, held at Hospital Beneficente Santa Helena (HBSH) in Cuiabá, State of Mato Grosso, Brazil. This study was approved by the Ethics in Research Committee of the Hospital Universitário Júlio Müller (Protocol 070/CEP-HUJM/2011) and all volunteers signed the informed consent formcontaining the description of the procedures involved in the project. The work was registered with the Brazilian Registry of Clinical Trials (http:/ /www.ensaiosclinicos.gov.br/) receiving the number RBR $4 \mathrm{rcsc} 6$

We included all adult, female patients aged between 18 and 60 years undergoing open

1. Faculdade de Medicina, Universidade Federal de Mato Grosso, Cuiabá, MT, Brasil. 
cholecystectomy, from December 2011 to March 2012. They should not have diabetes mellitus, chronic renal failure, clinically significant liver disease (history of jaundice, ascites, chronic alcoholism or chronic hepatitis), gastroesophageal reflux disease, achalasia, lung disease or heart disease, and should be classified with the ASA score (American Society of Anesthesiologists) class I or II. Regarding nutritional status, they should be nourished (ASG Subjective global assessment - A) and have body mass index (BMI) less than $35 \mathrm{Kg} / \mathrm{m}^{2}$.

The exclusion criteria were: patient not adherent to any phase of the study protocol, laparoscopic operations, need for immediate surgical intervention, major intraoperative complications, such as severe hypotension, cardiac arrest and bowel perforation. We also decided to exclude prolonged operations, lasting more than three hours.

We randomized patients following the precepts of the CONSORT Group ${ }^{17}$, through numbers random generation by a computer program (available at: www.graphpad.com) that determined which patient would be part of the control group and of the intervention one. This randomization was kept in a sealed envelope until the time of patients allocation. To collect data, six professionals were initially trained by the researcher and subsequently selected for HGS measurement. None of the examiners knew which patients belonged to eachgroup. Only one researcher knew the allocation of the groups, being the only one responsible for offering the carbohydrate-containing drink to selected patients and did not perform any measurements in the subjects. Patients who were in the intervention group also did not know the usefulness of the liquid ingested. Hospital discharge was determined by a doctor that was not informed of the ongoing study.

\section{Preoperative Protocol}

All patients were hospitalized in the morning of the operation day, and the procedures performed in the afternoon. They followed the routine fasting of minimum six hours for solid foods. Those who belonged to the intervention group received $400 \mathrm{ml}$ of a drink containing carbohydrate about six hours before the surgical procedure and $200 \mathrm{ml}$ two hours before the operation. This drink was manipulated and supplied by the hospital Nutrition and Dietetic Service. The drink contained $12.5 \%$ carbohydrate $(100 \%$ maltodextrin Carboplex, Advanced Nutrition, Rio de Janeiro, Brazil). The conventional group, in turn, remained in complete fasting with a minimum requirement of $6-8$ hours until the operation ${ }^{10}$.

\section{Postoperative protocol}

With the exception of short preoperative fasting, all patients received some of the prescriptions and guidelines recommended by the ACERTO Project protocol, already a routine in th service. Thus, all were instructed to early ambulation, intravenous fluids restriction (no volume or up to $20 \mathrm{ml} / \mathrm{kg} /$ day in the immediate postoperative), early oral refeeding, up to six hours after the operation and no use or minimal use of opioids for analgesia ${ }^{18}$. All patients received epidural anesthesia.

The HGS was measured by a dynamometer (Baseline ${ }^{\circledR}$, Pakistan) in both groups at admission (HGSPre), ie at 7am (six hours before surgery), in the immediate preoperative period ( $1 \mathrm{~h}$ before surgery; HGS-Im) and after the end of the operation (HGS-Post - 12-18h postoperatively), in the dominant and nondominant hands. To this we adopted the technique described by Mathiowetz et $a .^{19}$ and validated by Bragagnolo20. We made three measurements and considered the highest obtained value to express each patient's HGS.

\section{Statistical method}

We calculated a sample containing 12 patients in each group as being sufficient to obtain a beta error of $80 \%$ and analpha error of $5 \%$, estimating that there would be a reduction of HGS by $50 \%$ in the control group. We used the Fisher's exact test or the chi-square test to compare categorical variables.

For continuous data, we used the ANOVA test for repeated measures. We analyzed the results with the Statistical Package for Social Sciences (SPSS) for Windows 9.0, with the significance level of $5 \%(p<0.05)$.

\section{RESULTS}

Seventy-eight patients were eligible. Of these, 40 patients were randomized, with 21 and 19 for the intervention and control groups, respectively. Subsequently, 13 patients were excluded due to not following the perioperative protocol. Thus, 27 patients were analyzed, 14 in the intervention group and 13 in the control one (Figure 1). All patients were female and underwent cholecystectomyby laparotomy. Even presenting an age range 24 years (36 to 60), this did not affect the data obtained, since the force analysis was performed individually, comparing the individual's own strength, before and after surgery and/or after intake of the carbohydrate drink, there being no comparison between individuals. The distribution of cases according to the preoperatively demographic and clinical data in both groups is shown in table 1 . There were no deaths or postoperative complications in both groups. Control group patients were on average fasting for 19 hours (3-19 hours). All patients were discharged early (within 24 hours postoperatively).

The mean values found for the HGS measures are in table 2 and figure 2 . The group of patients who ingested the drink with $\mathrm{CHO}$ showed significantly higher HGS in at least one hand in the three periods. 


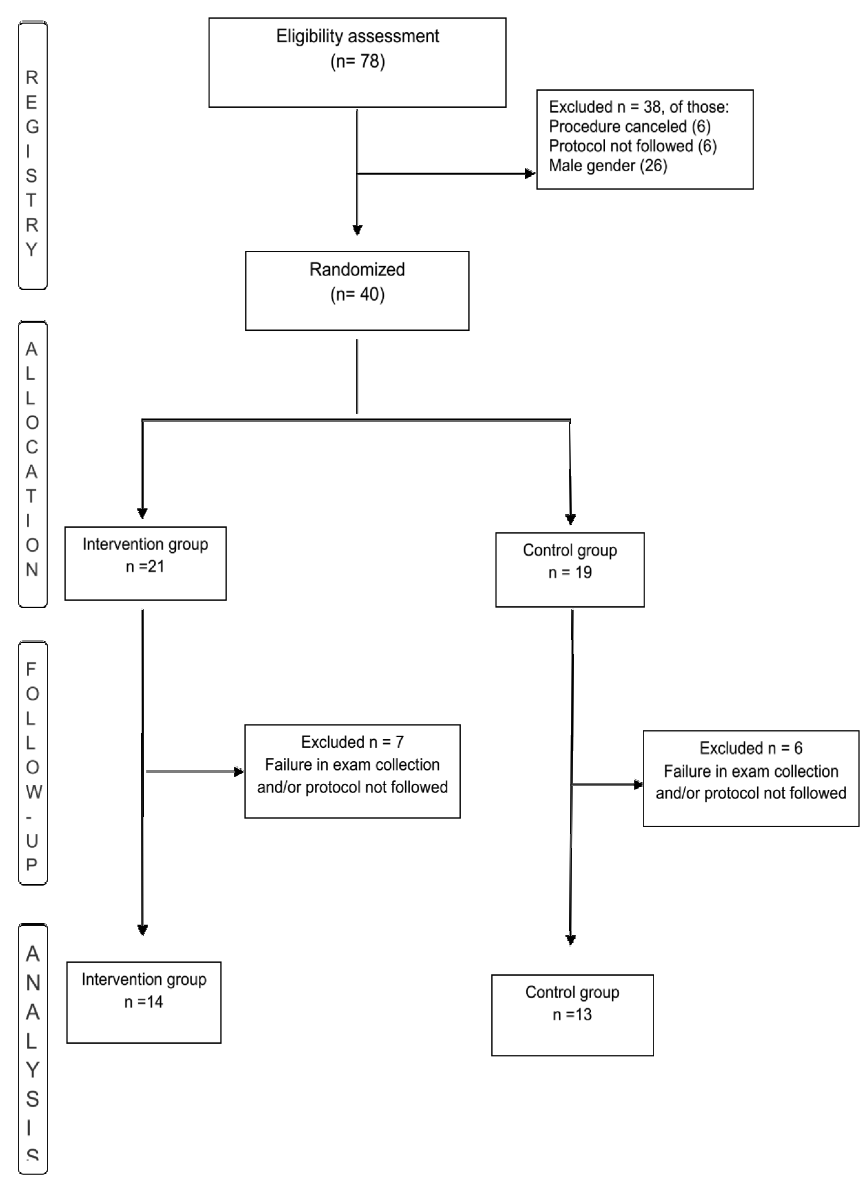

Figure 1 - Randomization Flowchart.

\section{DISCUSSION}

The results of this study support other studies that showed that the abbreviation of preoperative fasting with carbohydrate-containing beverage is safe and does not cause damage to the patient. On the contrary, the current data show that fasting abbreviation with $\mathrm{CHO}$ was associated with a significant increase in HGS in all phases of the study, suggesting that the abbreviation of fasting exerts a beneficial effect on muscle strength in patients undergoing cholecystectomy by laparotomy.
Our results agree with several studies that suggested benefits associated with intake of carbohydrates drinks two hours before the surgical procedure ${ }^{9,10,21}$. We observed, in agreement with other ACERTO group studies, that traditional fasting is in fact more dilated and is on average greater than eight hours ${ }^{8,22,23}$. In a multicenter national study called BIGFAST ${ }^{23}$, also held by the ACERTO group, we found that patients remain on average 12 hours in preoperative fasting, regardless of the prescription of preoperative fasting being based on traditional protocols (6-8 hours absolute fasting) or on modern ones (6-8 hours of fasting to solids, and clear liquids allowed up to two hours before surgery). In this study, the conventional group got an average of 19 hours fasting, similar to the average of some BIGFAST study hospitals. Unlike the other cited multicenter study, ours observed that patients in the intervention group stayed on average for only three hours of preoperative fasting, really approaching the prescribed routine, versus eight hours of real preoperative fasting observed in patients throughout Brazil when oriented in modern fasting protocols. Possible causes for this spacing of preoperative fasting, not measured in this study but identified in other works, are the changes in the scheduling of operations, delay in timing of operations, and the higher patient compliance to fasting, believing it to be more beneficial to herself ${ }^{23,24}$.

Several studies have solidified the reliability of anthropometric measurements taken in the individual's nondominant side, since it is the side that receives less external influences ${ }^{25}$. Corroborating this fact, the measurements taken in the non-dominant hand of the subjects studied in this work showed a significant difference between the control group and the intervention group immediately preoperatively and postoperatively, as a result of preoperative carbohydrate drink intake. At times, this influence was also found in the measurements of the dominant hand at the preoperative and immediate preoperative periods.

Noblett et al. ${ }^{13}$, when measuring the grip strength of their patients, also found a significant reduction of preoperative strength among patients who underwent

Table 1 - Demographic and clinical data of patients studied in both groups.

\begin{tabular}{|c|c|c|c|}
\hline Variable & Control Group & Intervention Group & $p$ (ANOVA test) \\
\hline Age (years) (mean and SD) & $48 \pm 12$ & $49 \pm 10$ & 0,89 \\
\hline Operative time (min) (mean and SD) & $84 \pm 31$ & \pm 26 & 0,39 \\
\hline Type of anesthesia (N,\%)Blockade & $13 \quad(100)$ & $(100)$ & 1,0 \\
\hline Preoperative fasting (hours) (mean and SD) & $19 \pm 3$ & $3 \pm 1$ & $<0,001$ \\
\hline Nutritional status (N,\%)Eutrophic & $13 \quad(100)$ & $14 \quad(100)$ & 1,0 \\
\hline $\mathrm{BMI}\left(\mathrm{kg} / \mathrm{m}^{2}\right)$ & $24,4 \pm \quad 5,4$ & $25,0 \pm \quad 3,9$ & 0,79 \\
\hline ASA Scorel & $13 \quad(100)$ & $14 \quad(100)$ & 1,0 \\
\hline
\end{tabular}

SD: Standard deviation

BMI: Body mass index

ASA: American Society of Anesthesiologists - physical evaluation score. 


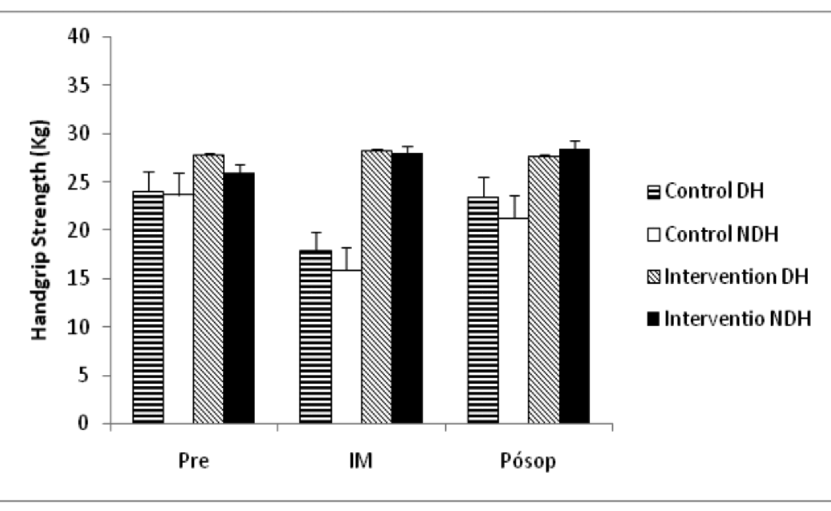

Figure 2 - Handgrip strength in the dominant and nondominant hands in the three observation periods in both groups.

$*, p<0.05$ (ANOVA) versus the control group in the same reference hand and the same observation period. Data represent mean and standard error.

Pre= Preoperative; $I M=$ immediate preoperative; Post= postoperative period; $\mathrm{DH}=$ dominant hand; $\mathrm{NDH}=$ non-dominant hand.

conventional fasting, but this reduction was not found in patients receiving water or $\mathrm{CHO}$.

Our results found a higher HGS in the intervention group. However, the lack of a group that received just water without $\mathrm{CHO}$ limits our conclusions. Therefore, we cannot clearly say whether this increase was due to the carbohydrate in the drink or simply because the patient is in an abbreviated fasting protocol. Indeed, Noblett et al. ${ }^{13}$ found an improvement of HGS both in the group that ingested only flavored water and in the group that ingested the drink containing carbohydrate before the operation. Still, be it due to the hydration or to the glycidic load of the drink, there was improvement in the individual's functional status, and this suggests that preoperative fasting abbreviation benefits patients.

Hunt et al. ${ }^{26}$ analyzed several nutritional status parameters, such as arm muscle circumference, forearm muscle circumference, triceps fold, ideal body weight percentage, serum albumin and usual weight percentage, in addition to the DM in surgical patients. They showed that DM was the most sensitive indicator among those to assess risk of postoperative complications and hospital stay. Accordingly, Bragagnolo et al. ${ }^{20}$ found that HGS is a good prognostic indicator in patients eligible for gastrointestinal surgery. In addition, Ali et al. ${ }^{27}$ evaluated patients in the intensive care unit and found that muscle strength is an independent predictor of hospital mortality. In major surgery, early ambulation is very important to reduce complications and speed recovery. Thus, a better-preserved muscle function is beneficial to the patient and is associated with lower rates of postoperative complications ${ }^{26}$.

In summary, our findings showed that candidates for cholecystectomy by laparotomy may benefit from fasting abbreviation two hours before the operation. These patients had greater muscle strength throughout the perioperative period. These data suggest that the nutritional and metabolic state was better preserved in this treatment group. Indeed, in the literature, there is evidence that the abbreviation of fasting reduces hospital stay, thus there may be a higher turnover of hospitalizations ${ }^{24}$.

Although with a small number of cases, these results are significant. We evaluated a sample of patients with good general condition, relatively young and without chronic diseases. In addition, the operation was appraised as medium-sized, and associated with a low risk of complications and mortality. This was a double blind, randomized study, which is an ideal study type to evaluate an intervention. Either way, the results are consistent with most of the literature and suggest the benefits of a beverage containing maltodextrin two hours before the operation $5,9,10,21,28$.

According to the results obtained in our study, we conclude that the abbreviation of preoperative fasting to two hours with acarbohydrate containing drink improves muscle strength in the perioperative period.

Table 2 - Results of measurements of Handgrip Strength pre and postoperatively in both groups. Data is expressed in mean and standard deviation.

\begin{tabular}{llrcc}
\hline Hand Grip Strength $(\mathrm{kg})$ & \multicolumn{2}{c}{ Control } & Intervention & $p$ (ANOVA test) \\
\hline Preoperative, dominant hand & 24.1 & $(3.7)$ & $27.8(2.6)$ & 0.04 \\
Preoperative, non-dominant hand & 23.7 & $(2.1)$ & $26.0(4.0)$ & 0.23 \\
Immediate preoperative, dominant hand & $17.9(12.8)$ & $28.3(2.7)$ & 0.03 \\
Immediate preoperative, non-dominant hand & $15.9(11.4)$ & $28.0(2.0)$ & 0.01 \\
Postoperative, dominant hand & 23.5 & $(6.6)$ & $27.7(4.0)$ & 0.19 \\
Postoperative, non-dominant hand & $21.3(5.9)$ & $28.5(3.0)$ & 0.01 \\
\hline
\end{tabular}


Objetivo: investigar os efeitos da abreviação do jejum pré-operatório com suplementação oral contendo carboidrato na evolução da força de preensão palmar em indivíduos submetidos à colecistectomia por laparotomia. Métodos: estudo clínico randomizado e duplo cego em pacientes adultos do sexo feminino, com idade entre 18 a 60 anos. Os pacientes foram divididos em dois grupos: grupo controle, com prescrição de jejum de 6-8h até o momento da operação e o grupo intervenção, que recebeu prescrição de jejum para sólidos de 6-8h, porém ingeriu um suplemento oral contendo 12,5\% de carboidrato, seis (400ml) e duas (200ml) horas antes do procedimento operatório. A força de preensão palmar foi aferida em ambas as mãos nos dois grupos, no momento de internação do paciente (6h antes da operação), no pré-operatório imediato (1h antes da operação) e com 12-18h de pós-operatório. Resultados: foram analisados 27 pacientes, 14 do grupo intervenção e 13 do grupo controle. Não houve mortalidade. A força de preensão palmar (média [desvio padrão] foi significantemente maior no grupo intervenção nos três períodos estudados, em ao menos uma das mãos: no pré-operatório na mão dominante $(27,8[2,6]$ vs. 24,1 [3,7] kg; $p=0,04)$, no pré-operatório imediato nas duas mãos, e no pós-operatório na mão não dominante $(28,5[3,0] \mathrm{vs} .21,3$ [5,9] kg; $p=0,01)$. Conclusão: a abreviação do jejum pré-operatório para duas horas com bebida contendo carboidrato melhora a função muscular no período perioperatório.

Descritores: Jejum. Carboidratos. Força Muscular. Colecistectomia. Cuidados Pré-Operatórios.

\section{REFERENCES}

1. Cook-Sather SD, Harris KA, Chiavacci R, Gallagher PR, Schreiner MS. A liberalized fasting guideline for formula-fed infants does not increase average gastric fluid volume before elective surgery. Anesth Analg. 2003;96(4):965-9.

2. Stuart, PC. The evidence base behind modern fasting guidelines. Best Pract Res Clin Anaesthesiol. 2006;20(3):457-69.

3. Søreide E, Eriksson LI, Hirlekar G, Eriksson H, Henneberg SW, Sandin R, et al. Pre-operative fasting guidelines: an update. Acta Anaesthesiol Scand. 2005;49(8):1041-7.

4. American Society of Anesthesiologists Committee. Practice guidelines for preoperative fasting and the use of pharmacologic agents to reduce the risk of pulmonary aspiration: application to healthy patients undergoing elective procedures: an updated report by the American Society of Anesthesiologists Committee on Standards and Practice Parameters. Anesthesiology. 2011;114(3):495-511.

5. Smith I, Kranke P, Murat I, Smith A, O'Sullivan G, Søreide E, et al. Perioperative fasting in adults and children: guidelines from the European Society of Anaesthesiology. Eur J Anaesthesiol. 2011;28(8):556-69.

6. Søreide $E$, Ljungqvist $O$. Modern preoperative fasting guidelines: a summary of the present recommendations and remaining questions. Best Pract Res Clin Anaesthesiol. 2006;20(3):483-91.

7. Weimann A, Braga M, Harsanyi L, Laviano A, Ljungqvist O, Soeters $P$, et al. ESPEN guidelines on enteral nutrition: surgery including organ transplantation. Clin Nutr. 2006;25(2):224-44.

8. Oliveira KGB, Balsan M, Oliveira SS, Aguilar-Nascimento JE. A abreviação do jejum pré-operatório para duas horas com carboidratos aumenta o risco anestésico? Rev Bras Anestesiol. 2009;59(5):57784.

9. Nygren J. The metabolic effects of fasting and surgery. Best Pract Res Clin Anaesthesiol. 2006;20(3):429-38.

10. Faria MS, Aguilar-Nascimento JE, Pimenta OS, Alvarenga LC Jr, Dock-Nascimento DB, et al. Preoperative fasting of 2 hours minimizes insulin resistance and organic response to trauma after video-cholecystectomy: a randomized, controlled, clinical trial. World J Surg. 2009;33(6):1158-64.

11. Thorell A, Nygren J, Essén P, Gutniak M, Loftenius A, Andersson B, et al. The metabolic response to cholecystectomy: insulin resistance after open compared with laparoscopic operation. Eur J Surg. 1996;162(3):187-91.

12. Bohannon RW. Dynamometer measurements of hand-grip strength predict multiple outcomes. Percept Mot Skills. 2001;93(2):323-8.
13. Noblett SE, Watson DS, Huong H, Davison B, Hainsworth PJ, Horgan AF. Pre-operative oral carbohydrate loading in colorectal surgery: a randomized controlled trial. Colorectal Dis. 2006;8(7):563-9.

14. Schlüssel MM, dos Anjos LA, de Vasconcellos MT, Kac G. Reference values of handgrip dynamometry of healthy adults: a populationbased study. Clin Nutr. 2008;27(4):601-7.

15. Hornby ST, Nunes QM, Hillman TE, Stanga Z, Neal KR, Rowlands $B J$, et al. Relationships between structural and functional measures of nutritional status in a normally nourished population. Clin Nutr. 2005;24(3):421-6.

16. Russell DM, Leiter LA, Whitwell J, Marliss EB, Jeejeebhoy KN. Skeletal muscle function during hypocaloric diets and fasting: a comparison with standard nutritional assessment parameters. Am J Clin Nutr. 1983;37(1):133-8.

17. Moher D, Schulz KF, Altman DG. The CONSORT statement: revised recommendations for improving the quality of reports of parallelgroup randomised trials. Lancet. 2001;357(9263):1191-4.

18. Aguilar-Nascimento JE, Caporossi C, Salomão AB. ACERTO - Acelerando a recuperação total pós-operatória. $2^{\text {a }}$ ed. Cuiabá: Rubio; 2011.

19. Mathiowetz V, Kashman N, Volland G, Weber K, Dowe M, Rogers S. Grip and pinch strength: normative data for adults. Arch Phys Med Rehabil. 1985;66(2):69-74

20. Bragagnolo R, Caporossi FS, Dock-Nascimento DB, Aguilar-Nascimento JE. Espessura do músculo adutor do polegar: um método rápido e confiável na avaliação nutricional de pacientes cirúrgicos. Rev Col Bras Cir. 2009;36(5):371-6.

21. Perrone F, da-Silva-Filho AC, Adôrno IF, Anabuki NT, Leal FS, Colombo $T$, et al. Effects of preoperative feeding with a whey protein plus carbohydrate drink on the acute phase response and insulin resistance. A randomized trial. Nutr J. 2011;10:66

22. Aguilar-Nascimento JE, Bicudo-Salomão A, Caporossi C. Silva RM, Cardoso EA, Santos TP. Acerto pós-operatório: avaliação dos resultados da implantação de um protocolo multidisciplinar de cuidados peri-operatórios em cirurgia geral. Rev Col Bras Cir. 2006;33(3):181-8.

23. de Aguilar-Nascimento JE, de Almeida Dias AL, Dock-Nascimento $D B$, Correia MI, Campos AC, Portari-Filho PE, et al. Actual preoperative fasting time in Brazilian hospitals: the BIGFAST multicenter study. Ther Clin Risk Manag. 2014;10:107-12.

24. Aguilar-Nascimento JE, Bicudo-Salomão A, Caporossi C, Silva RM, Cardoso EA, Santos TP. Enhancing surgical recovery in CentralWest Brazil: the ACERTO protocol results. e-SPEN, Eur J Clin Nutr Metab. 2008;3:e78-e83. 
25. Humphreys J, de la Maza P, Hirsch S, Barrera G, Gattas V, Bunout D. Muscle strength as a predictor of loss of functional status in hospitalized patients. Nutrition. 2002;18(7-8):616-20.

26. Hunt DR, Rowlands BJ, Johnston D. Hand grip strength-a simple prognostic indicator in surgical patients. JPEN J Parenter Enteral Nutr. 1985;9(6):701-4.

27. Ali NA, O'Brien JM Jr, Hoffmann SP, Phillips G, Garland A, Finley JC, et al. Acquired weakness, handgrip strength, and mortality in critically ill patients. Am J Respir Crit Care Med. 2008:178(3):2618.
28. Brady M, Kinn S, Stuart P. Preoperative fasting for adults to prevent perioperative complications. Cochrane Database Syst Rev. 2003;(4):CD004423.

Received in: 28/10/2015

Accepted for publication: 28/12/2015

Conflict of interest: none.

Source of funding: none.

\section{Mailing address:}

Marcella Giovana Gava

E-mail: marcellagava@hotmail.com 